通

\title{
Mendut and Pawon Temples Tourism Development Model in Magelang Regency
}

\author{
Elsa Aulia Brata ${ }^{凶}$ \\ Jurusan Ekonomi Pembangunan, Fakultas Ekonomi, Universitas Negeri Semarang \\ Permalink/DOI: https://doi.org/10.15294/efficient.v2i3.35907 \\ Received: Juny 2019 ; Accepted: September 2019; Published: December 2019
}

\begin{abstract}
Magelang Regency had the highest tourism revenue in Central Java. Mendut and Pawon temples include cultural tourism. But in recent years Mendut and Pawon temple tourism revenues did not meet the target. The purpose of this study was to analyze tourist preferences towards Mendut and Pawon Temple cultural attractions, analyze the development strategies that need to be carried out by the Magelang District Government in the development of Mendut and Pawon Temple cultural tourism, and analyze alternative development models of Mendut and Pawon Temples. The population in the study were tourists who visited Mendut and Pawon temple attractions. The number of research samples was 100 tourists and 2 keypersons and were taken purposively. Data collection methods use questionnaires and interviews. The results showed that analysis of the tourist preferences of Mendut Temple was the best aspect of location comfort while Candi Pawon was the best aspect of accessibility, the development strategies of Mendut and Pawon temples in the Matrix Grand Strategy are both in quadrant 1 , there are alternative development models of Mendut and Pawon temples that involve the community. Implications of the research of this study is the existence of collaboration between relevant agencies to develop both development and tourism to attract tourists, in addition to the promotion of Mendut and Pawon Temple cultural tourism was again enhanced.
\end{abstract}

Keywords: Development Model, Preference, SWOT

\begin{abstract}
Abstrak
Kabupaten Magelang memiliki pendapatan wisata tertinggi di Jawa Tengah. Candi Mendut dan Pawon termasuk wisata budaya. Namun dalam beberapa tahun terakhir pendapatan pariwisata Candi Mendut dan Pawon tidak memenuhi target. Tujuan dari penelitian ini adalah untuk menganalisis preferensi wisatawan terhadap objek wisata budaya Candi Mendut dan Pawon, menganalisis strategi pengembangan yang perlu dilakukan oleh Pemerintah Kabupaten Magelang dalam pengembangan wisata budaya Candi Mendut dan Candi Pawon, serta menganalisis model pengembangan alternatif Candi Mendut dan Pawon. Populasi dalam penelitian ini adalah wisatawan yang mengunjungi objek wisata Candi Mendut dan Pawon. Jumlah sampel penelitian adalah ioo wisatawan dan 2 keypersons dan diambil secara sengaja. Metode pengumpulan data menggunakan kuesioner dan wawancara. Hasil penelitian menunjukkan bahwa analisis preferensi wisatawan dari Candi Mendut adalah aspek terbaik dari kenyamanan lokasi sedangkan Candi Pawon adalah aspek terbaik dari aksesibilitas, strategi pengembangan candi Mendut dan Pawon dalam Matriks Grand Strategy keduanya berada di kuadran 1, ada model pengembangan alternatif candi Mendut dan Pawon yang melibatkan masyarakat. Implikasi dari penelitian penelitian ini adalah adanya kolaborasi antara instansi terkait untuk mengembangkan pembangunan dan pariwisata untuk menarik wisatawan, selain promosi wisata budaya Candi Mendut dan Candi Pawon pun kembali ditingkatkan.
\end{abstract}

Kata Kunci: Model Pengembangan, Preferensi, SWOT

How to Cite: Brata, E. (2019). Mendut and Pawon Temples Tourism Development Model in Magelang Regency. Efficient: Indonesian Journal of Development Economics, $2(3), \quad 540-552$. https://doi.org/10.15294/efficient.v2i3.35907

(C) 2019 Semarang State University. All rights reserved

\footnotetext{
Alamat Korespondensi :

Alamat: Gedung L2 Lantai 2 FE Unnes

Kampus Sekaran, Gunungpati, Semarang, 50229

E-mail : elsabrata12@gmail.com
}

ISSN 2655-6197 


\section{INTRODUCTION}

Tourism is a sector that is being discussed by many parties. The potential of a tourist attraction can be utilized properly through the development of a tourist attraction. With the development of tourism objects will add to the tourist attraction of tourism.

According Hanif (2018) the tourism sector is a strategic sector in Indonesia in national economic development, in which the government has just realized tourism as a potential sector for economic drivers in Indonesia with a variety of tourism attractions can attract both local and foreign tourists.

Tourism in an area needs to be developed especially in the development of tourism objects, so that more tourist attractions can be made. With the tourist attraction there will be many tourists both local and foreign tourists who visit to travel in the area, it can increase the level of tourism visits in the area. In line Fitrianti (2014) the tourism sector is one sector that can be developed as a source of regional income, so it is expected to be able to support economic development.

Magelang regency which is located between Semarang city and Yogyakarta city has a strategic location to develop the tourism potential. With the Borobudur temple increasingly inviting tourists to visit and travel in Magelang regency, especially for foreign tourists who are always interested in traveling to Borobudur temple, there are still many tourist attractions in Magelang regency besides Borobudur Temple, especially other cultural attractions.The development of cultural tourism in addition to Borobudur Temple in Magelang regency is expected to increase the tourism sector revenue in Magelang regency and increase the number of tourists visiting both domestic tourists and foreign tourists. But there are still many tourists who do not know about cultural tourism other than Borobudur Temple, so that other cultural attractions are still far behind with the development of Borobudur temple including the development of Mendut and Pawon temples in Magelang regency which is still very simple in development. Therefore, it is necessary to know the needs and desires of tourists so that Mendut and Pawon temple cultural attractions can be developed according to the wishes of tourists.

Table 1. Mendut and Pawon Temple Revenues in 2012-2016

\begin{tabular}{|c|c|c|}
\hline & Year & Revenues \\
\hline \multicolumn{3}{|l|}{ No } \\
\hline & 2012 & Rp 88.694.575 \\
\hline & 2013 & Rp 114.686.275 \\
\hline & 2014 & Rp 111.680.570 \\
\hline & 2015 & Rp 90.277.995 \\
\hline & 2016 & Rp 101.588.585 \\
\hline
\end{tabular}

Source: Department of Tourism, Youth and Sports of Magelang Regency

Table 1 it can be seen that tourism revenues derived from Mendut and Pawon temple fees from 2012-2016 getting fluctuations. The tourism revenue of Mendut temple was merged with Pawon temple because the management of the two temples was managed into one. Mendut and Pawon temple managers are the Magelang Regency Tourism, Youth and Sports Department in collaboration with Borobudur Conservation Center which is also in Magelang regency. 
Table 2 shows that the revenue but still the revenue of Mendut and Pawon realization of Mendut and Pawon temples did not meet the target in 2012-2016, from the target that continued to increase every year temples could not meet the target set by the District Tourism, Youth and Sports Department Magelang.

Table 2. Percentage of Realization of Mendut and Pawon Temple Tourism Revenues in 2012-2016

\begin{tabular}{llll}
\hline Year & Target & Realization & $(\%)$ \\
\hline 2012 & Rp 67.000.000 & Rp 88.694.575 & 132,38 \\
2013 & Rp 150.000.000 & Rp 114.686.275 & 76,46 \\
2014 & Rp 150.000.000 & Rp 111.680.570 & 74,75 \\
2015 & Rp 159.100.000 & Rp 90.277.995 & 56,74 \\
2016 & Rp 160.000.000 & Rp 101.588.585 & 63,49 \\
\hline
\end{tabular}

Source: Department of Tourism, Youth and Sports of Magelang Regency

According to Arsyad (2010) regional economic development is a process in which the local government and its people manage every available resource and form a partnership pattern between the local government and the private sector to create a new job and stimulate the development of economic activities (economic growth) and the region. Meanwhile, regional development is a development that is intended to encourage, empower the community, foster initiatives and improve community welfare (Rahman \& Chamelia 2015).

Realizing one of the realities of development is the creation of development gaps between regions and between regions (Pujiati, 2009). Tourism is one sector that can be used as regional economic development, because the tourism sector is able to absorb tourists who want to pay to enjoy tourism and can absorb local workers and be able to empower the economic activities of surrounding communities.

According to Spillane (1991) the tourism industry has special properties such as tourism products cannot be moved but consumers themselves who comes to visit and enjoy tourism objects, production and consumption occur at the same time, and tourism products contain high risks because they require very large capital, while the request is very sensitive. The development of tourism objects can be used as a driving factor for tourists to visit or tour the tourist attraction. In line with Pradikta (2013) in developing these tourism objects must pay attention to the socio-economic conditions of the local community, the social culture of the local area, religious values, customs, environment, and the tourism object itself.

According to Yoeti (2008) the principle of developing and managing a tourism object is as follows:

a. Having one unit with regional or national development from the economic development of a country.

b. The development and maintenance of tourism requires an integrated approach with other sectors, especially 
the agricultural sector, services, trade and the transportation sector.

c. Tourism must be based on a study that is specifically made for these tourism objects and by taking into account the environmental protection of the natural environment and culture in the area concerned.

d. The development of tourism in a tourism object must be followed by the overall physical development in question.

e. The purpose of tourism is not only concerned with administrative aspects but also based on the relevant research and the quality of Human Resources.

Magelang Regency is the region that has the highest level of tourist visits in Central Java Province. Preference is something that is more desirable or as a necessity, a choice of the main tourist objects, is a priority need and gives good advantage to make tourism objects develop according to the tourist's desire. The trip selection process is the main color provider and the first driver until someone wants to know more about a destination. Tourist curiosity can be raised with marketing or promotion. Tourist preferences arise in the desires and needs of tourists who travel to tourism products. The desire and needs of tourists towards tourism products are increasingly complex, dynamic and demand adequate quality and are associated with the principles of sustainable development. Consequently, a tourist destination must be able to adapt to all the demands of change by listening to the voices of various interested parties, especially tourists whohave different perceptions and preferences in choosing attractions to be visited by Alam (2010 in Pauwah, 2013).
Tourism activists like the government, business people, the private sector, and local communities should work together and support each other in developing tourism, especially in the field of cultural tourism (Khaironi et al., 2017). According to Stanton (1999 in Gantini, 2012) as for the factors that often influence preferences among tourism consumers (tourists) in choosing tourist objects, they are location convenience, services provided, ease of accessibility, complete facilities, attractive atmosphere (tourist attraction)

The purpose of this study was to analyze tourist preferences on Mendut and Pawon temple cultural attractions, to know and analyze the development strategies that need to be carried out by the Magelang District Government in developing cultural tourism of Mendut and Pawon temples, and to know and analyze old development and management models at Mendut temple attractions and Pawon, making alternative development models for Mendut and Pawon temples in Magelang district.

\section{METHOD}

This research was quantitative. This study uses a descriptive approach. The sample of this study were 100 samples or respondents from Mendut and Pawon temple cultural tourism visitors in Magelang regency, plus 2 persons consisting of 1 employee of the Borobudur Conservation Center and 1 employee of the Magelang Regency Tourism, Youth and Sports Service, so the number of respondents this study was 102 respondents.

Variables from the study of tourist preferences on Mendut and Pawon temple cultural attractions in Magelang Regency 
include location comfort. Indicators of location convenience are, a sense of comfort of tourists towards attractions, tourist safety against attractions, local citizen's attitude towards tourists. Ease of Accessibility. Indicators of ease of accessibility, namely availability of transportation in tourist attractions, ease of tourists with private vehicles, ease of tourists with public transportation, telecommunication networks in tourist attractions, facilities completeness. Facility completeness indicators are places to eat, rest area, worship place, parking lot, toilet. Tourist Attraction. Indicators of tourist attraction are sightseeing attraction, types of attractions in attractions, tourist attractions. Services Provided. Indicators of services provided are promotion of attractions, information about attractions, quality of service to tourists.

Variables of Mendut temple and Pawon temple development strategy research are internal factor variables as follows tourist attractions, labor, management, facilities, promotion.

While the external factor variables in this study include accessibility, tourist interest, environment,ompetitiveness with other attractions, government support

The research variables of the development and management model of Mendut Temple and Pawon Temple in Magelang Regency are related institutions, financial management, maintenance, development, recruitment of human resources.

The data used in this study were primary and secondary data. The primary data of this study were data obtained from respondents, namely visitors of tourism objects, employees of the Borobudur
Conservation Center and employees of the Department of Tourism, Youth and Sports of Magelang Regency. This primary data was obtained by means of interviews and questionnaires.

Secondary data was obtained from the Department of Culture and Tourism of the Province of Central Java and the Department of Tourism, Youth and Sports of the Magelang Regency.

\section{RESULTS AND DISCUSSION}

\section{Tourist Preferences}

The existence of the needs of tourists who cause desires in a tourist attraction can lead to tourist preferences. Tourist preferences are used to measure the needs and desires of tourists towards Mendut Temple and Pawon Temple cultural attractions in Magelang Regency.

In this study, to measure the level of tourist preference towards Mendut and Pawon Temple cultural attractions in Magelang Regency, there are five aspects with several indicators. These five aspects are the convenience of the location, accessibility, accessibility of facilities, tourist attractions, and services provided.

Table 3 shows that the highest level of preference at Mendut Temple is the comfort aspect of the location with a percentage of $22 \%$ and good category. Location comfort is indeed felt in Mendut Temple's cultural tourism objects, the atmosphere is calm, safe and the attitude of the local community is friendly so that the tourists feel happy to tour Mendut Temple. Besides that, cleanliness around Mendut Temple is always maintained, thus increasing the comfort of tourists to tour 
Mendut Temple. The completeness of the facilities is the lowest aspect of Mendut

Temple, the facilities in Mendut Temple need development and renovation because there are some facilities in Mendut Temple that are no longer suitable for use.

Table 3. Tourist Preferences Mendut Temple Attractions in Magelang District

\begin{tabular}{llll}
\hline Aspect & $\begin{array}{l}\text { Average } \\
\text { weight }\end{array}$ & Percentage & Category \\
\hline $\begin{array}{l}\text { Confienience } \\
\text { of the }\end{array}$ & 3,8 & $\mathbf{2 2} \%$ & Good \\
$\begin{array}{l}\text { Location } \\
\text { Ease of }\end{array}$ & 3,5 & $20 \%$ & $\begin{array}{l}\text { Good } \\
\text { Enough } \\
\text { Accessibility }\end{array}$ \\
$\begin{array}{l}\text { Facilities } \\
\text { Completeness }\end{array}$ & 3,3 & $19 \%$ & $\begin{array}{l}\text { Good } \\
\text { Enough } \\
\text { Tourist } \\
\text { attraction }\end{array}$ \\
$\begin{array}{l}\text { Services } \\
\text { provided }\end{array}$ & 3,49 & $20 \%$ & $\begin{array}{l}\text { Good } \\
\text { Enough } \\
\text { Good }\end{array}$ \\
\hline
\end{tabular}

Source: Primary data processed 2018

Table 4 shows that the average Pawon Temple tourist preference has a fairly good category. However, the aspects of completeness of facilities and services provided produce unfavorable categories. Facilities that are owned by Candi Pawon still do not need improvement and development, while services provided such as tour guides also do not yet exist. Although the comfort of the Pawon Temple location is good enough, it is still inferior to Mendut Temple.

From the results of research on tourist preferences in Mendut and Pawon Temples and through interviews of 2 key persons namely employees of the Department of Tourism, Youth and Sports and employees of the Borobudur Conservation Center, internal and external factors of Mendut Temple and Pawon Temple cultural attractions in Magelang Regency are as follows :

Table 4. Tourist Preferences Pawon Temple Attractions in Magelang District

\begin{tabular}{llll}
\hline Aspect & $\begin{array}{l}\text { Average } \\
\text { weight }\end{array}$ & Percentage & Category \\
\hline $\begin{array}{l}\text { Confienienc } \\
\text { e of the }\end{array}$ & 2,9 & $21 \%$ & $\begin{array}{l}\text { Good } \\
\text { Enough }\end{array}$ \\
$\begin{array}{l}\text { Location } \\
\text { Ease of }\end{array}$ & 3,04 & $\mathbf{2 2} \%$ & $\begin{array}{l}\text { Good } \\
\text { Eccessibility }\end{array}$ \\
$\begin{array}{l}\text { Facilities } \\
\text { Completene }\end{array}$ & 2,55 & $18 \%$ & Not good \\
ss & & & \\
Tourist & 2,93 & $21 \%$ & $\begin{array}{l}\text { Good } \\
\text { attraction }\end{array}$ \\
$\begin{array}{l}\text { Services } \\
\text { provided }\end{array}$ & 2,56 & $18 \%$ & Not good \\
Source: Primary data processed 2018 & \\
\hline
\end{tabular}

Strenght are the strategic location of Mendut Temple and Pawon Temple, comfortable atmosphere at Mendut Temple and Pawon Temple attractions, the existence of supporting transportation facilities, affordable ticket prices, friendliness of the people around Mendut Temple and Pawon Temple to tourists, professional management of Mendut Temple and Pawon Temple attractions, cleanliness of Mendut Temple and Pawon Temple attractions.

Weakness are lack of attractions owned by Mendut Temple and Pawon Temple, the lack of facilities possessed by Mendut Temple and Pawon Temple, the development of Mendut Temple and Pawon Temple is still simple, lack of promotion from Mendut 
Temple and Pawon Temple attractions, the land owned by Mendut Temple and Pawon Temple is very limited so it is difficult to develop.

Opportunity are the accessibility level of Mendut Temple and Pawon Temple is easy, the collaboration between Mendut Temple and Candi Pawon managers and related institutions, regional autonomy gives flexibility to develop existing tourism promotions, the surrounding environment of Mendut Temple and Pawon Temple in the form of countryside and culture can be developed and become a tourist attraction of Mendut Temple and Pawon Temple, the potential of Pawon Temple has a potential to lead to character and cultural education today.

Threat are the existence of other tourist objects that began to emerge and develop added competitiveness, there are potential similarities with attractions in other regions, the environmental damage around Mendut Temple and Pawon Temple, interest of tourists who start a little to visit cultural attractions such as Mendut Temple and Pawon Temple,

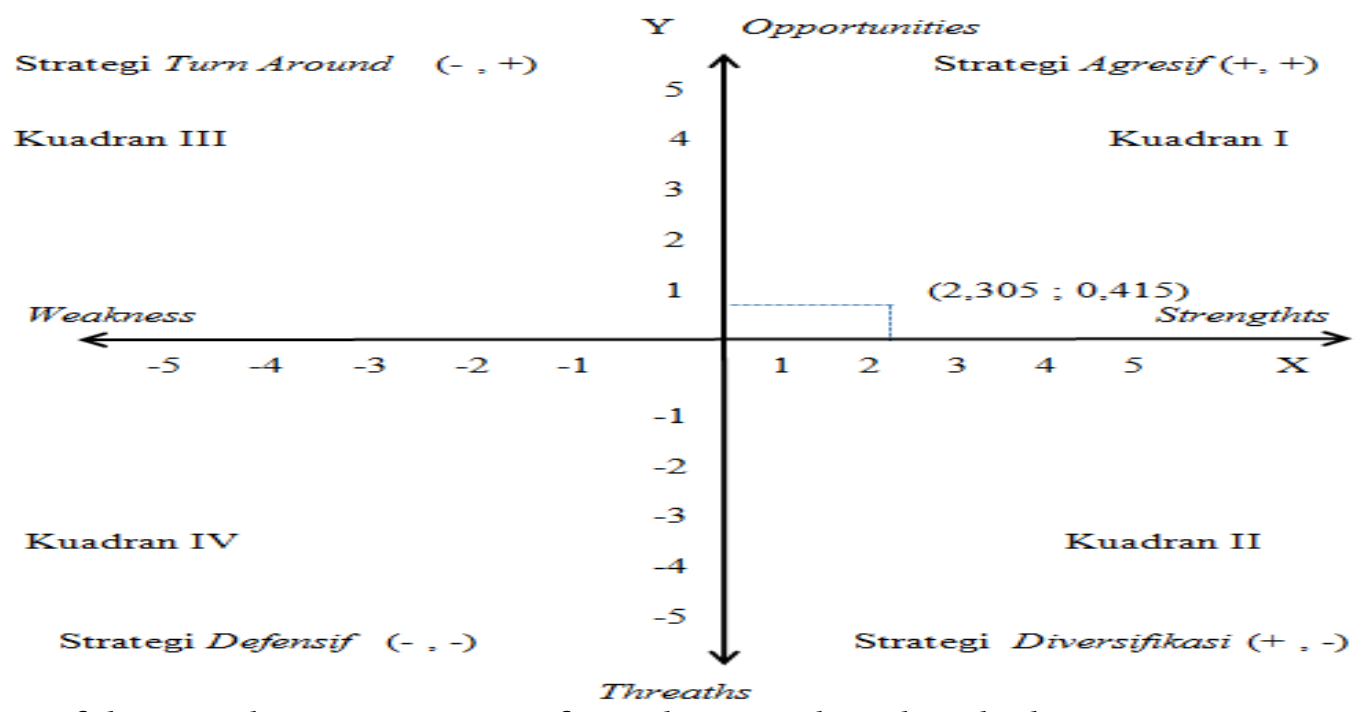

Picture 1. Of the Grand Strategy Matrix of Mendut Temple Cultural Objects

Source: Primary data processed 2018

the awareness of tourists to keep the Mendut Temple and Pawon Temple attractions is still low, the distance between the highway and the large cargo with Mendut Temple and Pawon Temple is too close

The results of the average weighting and rating of Mendut and Pawon temples. Table 5 ini appendix shows the strength and score score of the weakness of the internal strategy factor of Mendut Temple cultural tourism objects obtained from the internal strategy of strength. The number of strength scores obtained from the internal strategy factor of Mendut Temple strength was 2.94 and the number of weakness scores obtained from the internal strategy factors of Mendut Temple weakness was 0.635 .

Table 6 in appendix obtained opportunity scores and threat scores obtained from external strategic factors of opportunities and threats. The number of opportunity scores obtained from the external strategy factor of the Mendut Temple opportunity was 1.75 and the total score of the external strategic threat factor was 1.335 . 
Picture 1 above shows the intersection (2.305; 0.415) in quadrant I, where quadrant I is a position by maximizing the strengths and opportunities maximally in order to increase the growth of Mendut Temple cultural attractions. By utilizing the strengths and opportunities they have, it can accelerate the development of strategies that can be applied in these conditions by supporting aggressive strategies.

Table 7 in appendix shows the number of strength scores obtained from the internal strategy factor of Candi Pawon strength is 2.77 and the number of weakness scores obtained from the internal strategy of weakness of Candi Pawon is 0.525 .

Table 8 in appendix shows that opportunity scores and threat scores are obtained from external strategic factors of opportunities and threats. The number of opportunity scores obtained from the external strategy factor of the opportunity of Candi Pawon is 1.875 and the total score of the external strategic threat factor is $\mathbf{1 . 2 7}$.

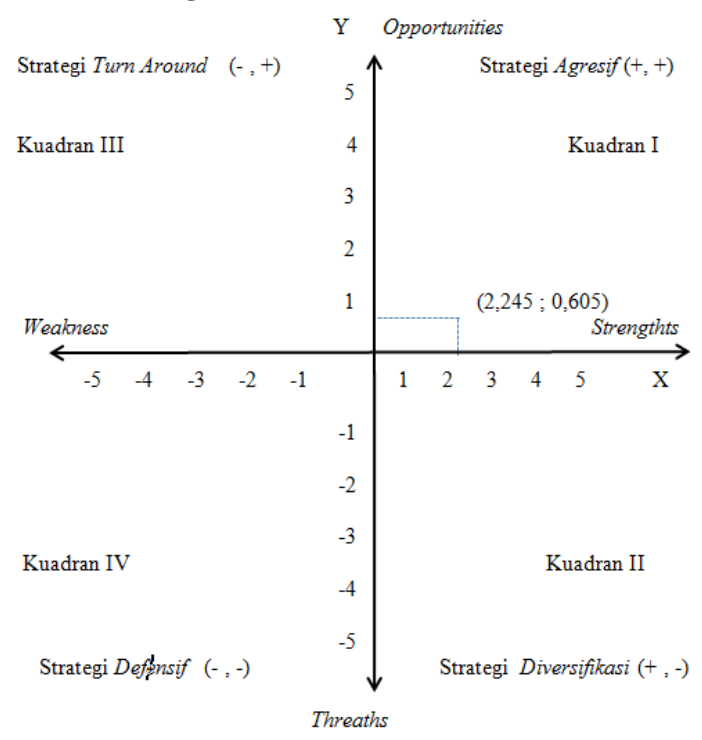

Picture 2. Temple Pawon Matrix Grand Strategy

Source: Primary data processed 2018
Picture 2 above shows the intersection (2.245; 0.605) in quadrant I, where quadrant I is a position by maximizing the strengths and opportunities maximally in order to increase the growth of Candi Pawon cultural attractions. By utilizing the strengths and opportunities they have, they can accelerate the development of strategies that can be applied in these conditions by supporting aggressive strategies.

To develop the Mendut Temple and the Pawon Temple of the Local Government of Magelang Regency, the Magelang Regency Tourism, Youth and Sports Department in collaboration with the Borobudur Conservation Center. For the Department of Tourism, Youth and Sports of Magelang Regency in the field of tourism management and Borobudur Conservation Center in the field of conservation management. In an effort to develop the potential of these two objects, the role of the Magelang District Government and the Borobudur Conservation Center are in collaboration with the Village Government or the surrounding community and also collaborate with academics. However, the Magelang District Government has not cooperated with the private sector to develop the potential of Mendut Temple and Pawon Temple.

Workers at Mendut and Candi Pawon temples consist of civil servants in the Magelang regency government, staff of the Borobudur Conservation Center, and several communities around Mendut Temple and Pawon Temple. In Mendut Temple there are 8 daily workers from the surrounding community and 4 civil servants, while Candi Pawon has 2 daily workers from the surrounding community and 2 civil servants, 
the civil servants in Mendut Temple and Pawon Temple have a conservationist background. Mendut Temple and Pawon Temple development program conducted by the Local Government of Magelang Regency and Borobudur Conservation Center is a program to improve parking lots, merchants, souvenirs, and ring roads. In addition, there is maintenance in the form of site repairs, such as the environment and site area every year.

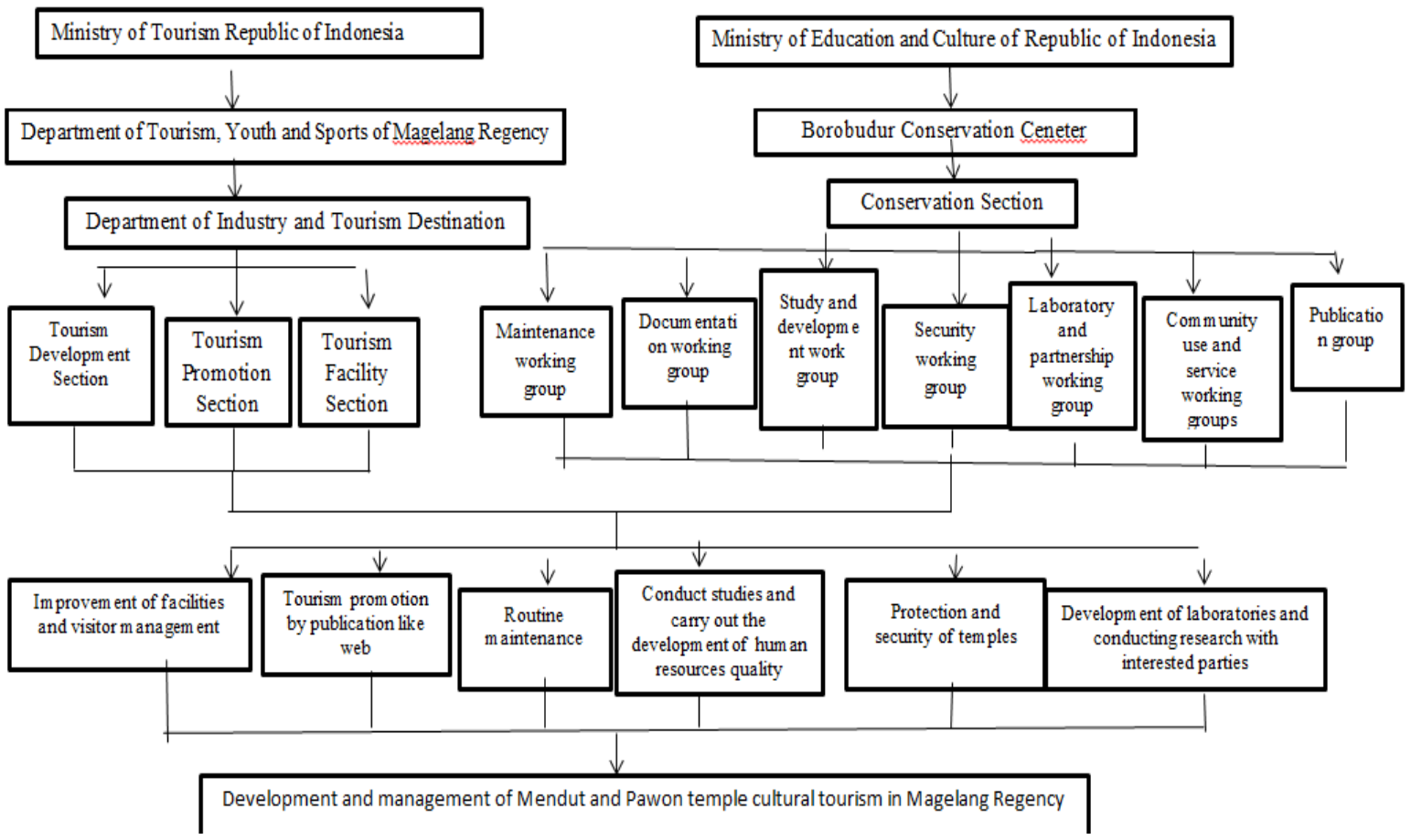

Picture 3. Chart of Mendut and Pawon Temple Development Models

Source: Primary data processed 2018

Picture 3 shows the development model of Mendut and Pawon temples according to interviews conducted with employees of the Department of Tourism, Youth, and Sports and the Borobudur Conservation Center. For the development of a collaboration between the Department of Tourism, Youth, and Sports and the Borobudur Conservation Center.From the Industry and Tourism Sectors and the Conservation Section each has sections and working groups, each of which has duties and works together to develop the Mendut and Pawon temples. The section and working group's task can be combined to undertake Mendut and Pawon Temples cultural tourism development efforts.

These tasks are the improvement of visitor facilities and management, tourism promotion with web publication, maintenance and routine maintenance, conducting study studies and carrying out the development of human resources quality, protection and security of Mendut and Pawon temples, and developing laboratories, and conducting research with parties of interest. But from the results of Mendut and Pawon temples tourist 
preferences and cultural development that this alternative model can develop strategies advantages and disadvantages are Mendut and Pawon Temples cultural known. This can create alternative models for attractions. Mendut and Pawon temples. With the hope

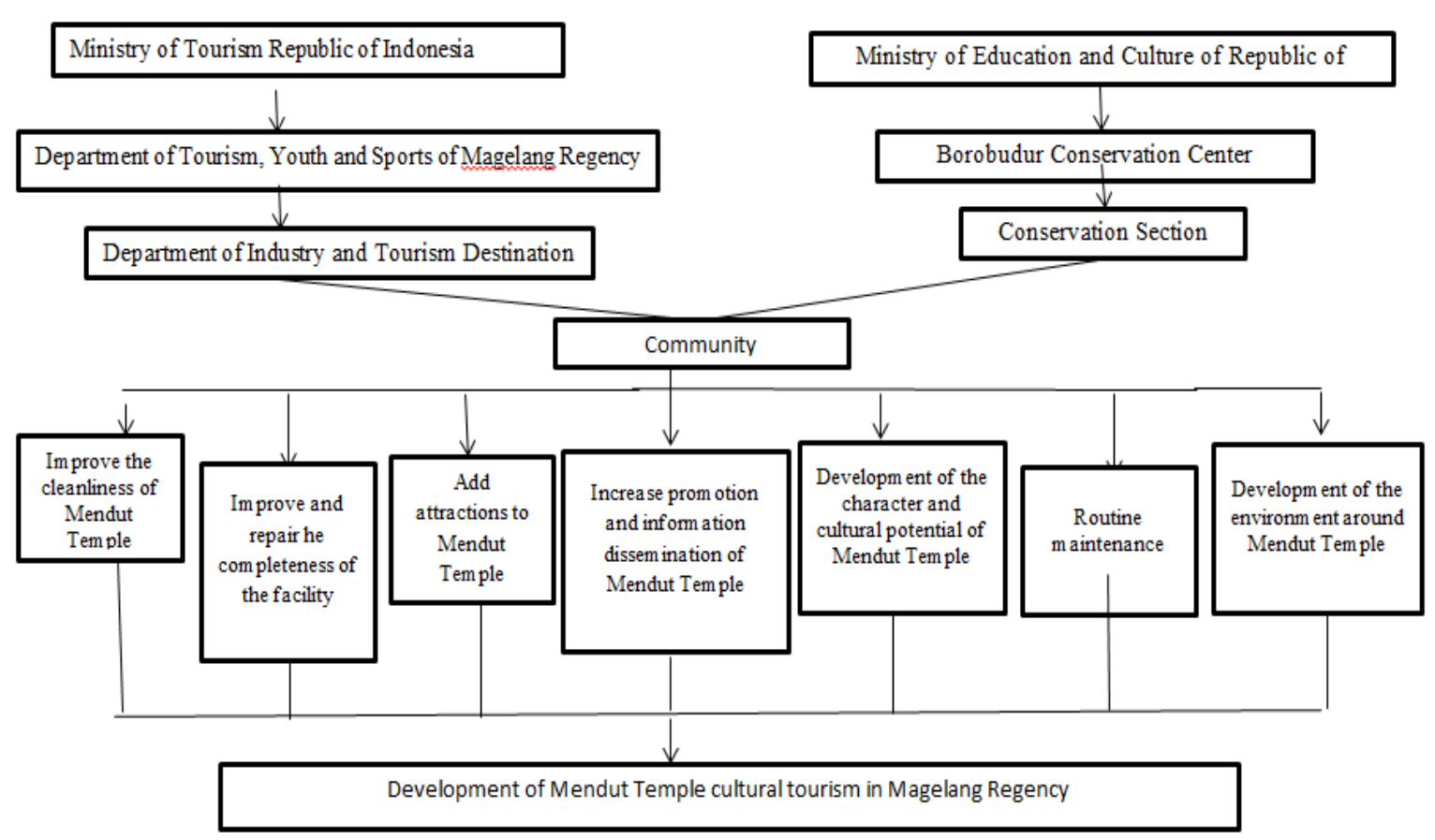

Picture 4. Mendut Temple Alternative Development Model Chart Source: Primary data processed 2018

Picture 4 above is an alternative model of Mendut Temple tourism development, aforementioned model combines research on tourist preferences and development strategies that are still not good at Mendut Temple. With this alternative model, the Department of Tourism, Youth, and Sports of Magelang Regency and Borobudur Conservation Center can work together in developing Mendut Temple according to the model.

Cleanliness in Mendut Temple needs to be improved so that tourists feel comfortable with Mendut Temple, the facilities at Mendut Temple are complete but improvement is needed. Attractions are needed to entice tourist appeal so that tourists will visit Mendut Temple, increasing tourism promotion at Mendut Temple and spread information about Mendut Temple tours because many tourists do not know the existence of Mendut Temple.

The character and culture of Mendut Temple can be used as a potential or as a tourist attraction, upkeep and routine maintenance done at Mendut Temple so that the site and environment of the temple are not damaged, and the development of the environment around Mendut Temple which is still beautiful can be developed into a tourist 
village as a tourist appeal for Mendut Temple. community.

This tourism village can collaborate with the

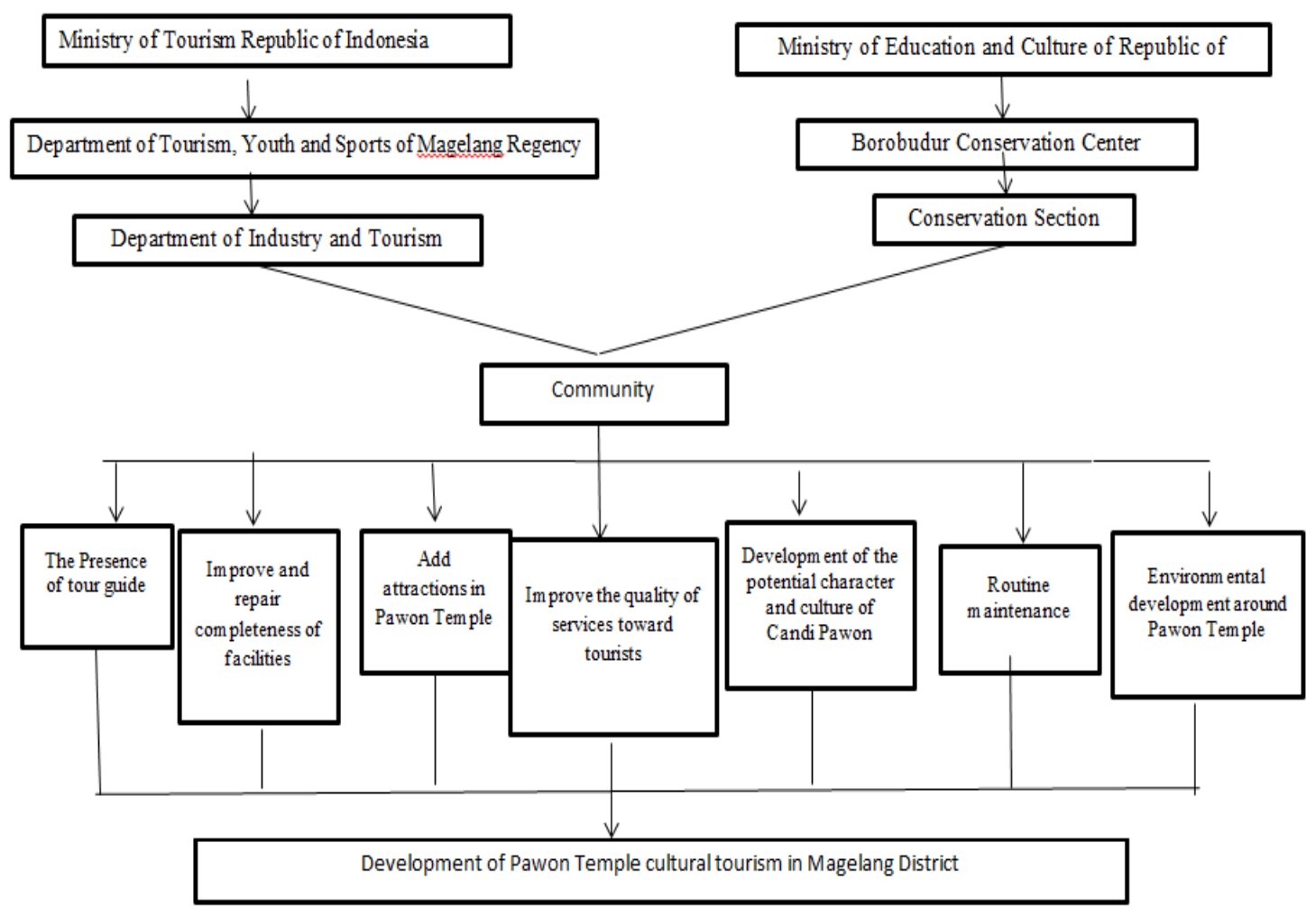

Picture 5. Candi Pawon Alternative Development Model Chart

Source: Primary data processed 2018

Picture 5 above is an alternative model of Mendut Temple tourism development, the alternative model combines research on tourist preferences and development strategies that are still not good at Temple Pawon. With this alternative model the Department of Tourism, Youth, and Sports of Magelang Regency and Borobudur Conservation Center can work together in developing Mendut Temple according to the model.

The need for tour guides to guide tourists traveling to Pawon Temple, facilities at Temple Pawon are still not good and addition and repair are needed, holding events or attractions that can be used as tourist appeal, improving the quality of service to tourists such as tour guides, parking attendants, and managers.

The character and culture of Pawon Temple can be used as a potential or as a tourist attraction, upkeep and routine maintenance done at Pawon Temple so that the temple site and environment are not damaged, and the development of the surrounding environment of Pawon Temple which is still beautiful can be developed into a tourist village as a tourist appeal for Pawon Temple. This tourism village can collaborate 
with the community. With this Pawon Temple alternative model, it is expected to help in the development of Pawon Temple cultural attractions. Because, this alternative model is arranged based on research aimed at tourists visiting the Pawon Temple.

The results of this study are in line with the theory of regional economic development according to Arsyad (2010) that in regional economic development is a process in which the local governments and its communities manage every available resources and form a pattern of partnership between local government and the private sector to create a new employment and stimulates the development of economic activities (economic growth) and the region. In Mendut and Pawon Temples, the partnership system of surrounding community has been carried out in collaboration in the form of shops that sell souvenirs, places to eat, and toilets as well as parking management.

With the collaboration between the Central Government and the Regional Government in preserving and developing Mendut Temple and Pawon Temple cultural attractions will impact the economic growth in the surrounding community. The impact could be the emergence of new economic nodes around Mendut Temple and Pawon Temple in Magelang Regency.

\section{CONCLUSION}

Based on the results of this study, the following conclusions are obtained: Tourist preferences in Mendut and Pawon Temple cultural tourism objects in 2018 according to the five aspects are as follows;

For the location comfort aspect, Mendut Temple gets a good category with a percentage of $22 \%$ while Pawon Temple gets a pretty good category with a percentage of $21 \%$.

In terms of ease of accessibility, Mendut Temple and Pawon Temple both get pretty good categories. Mendut Temple with a percentage of $20 \%$ and Pawon Temple $22 \%$.

In the facility completeness aspect, Mendut Temple gets a pretty good category with a percentage of $19 \%$ while Pawon Temple gets a pretty bad category with a percentage of $18 \%$. In the tourist attraction aspect, Mendut Temple and Pawon Temple both get quite good categories. Mendut Temple with a percentage of $20 \%$ and Pawon Temple $21 \%$.

Finally, in the service provided aspect, Mendut Temple gets a pretty good category with a percentage of $19 \%$ and Pawon Temple gets a pretty bad category with a percentage of $18 \%$.In the development strategy of Mendut and Pawon temples, the results of Mendut Temple's internal factors were 2,305 and the results of external factors of Mendut Temple were 0,415 while the results of Pawon Temple's internal factors were 2,245 and the results of the external factors of Pawon Temple were o,605. Mendut and Pawon temples are in quadrant $\mathrm{I}$, where quadrant $\mathrm{I}$ is a position of maximizing the power and opportunity to increase the growth of Mendut Temple and Pawon Temple cultural attractions.

The Mendut Temple and Pawon Temple cultural tourism development model is managed by the Government of Magelang Regency, namely the Department of Tourism, Youth, and Sports and the Borobudur Conservation Center. Development consists of tourism development and conservation development. Development is carried out is in the form of improvements to visitor facilities and management, site repairs, environment 
and site area maintenance, and conducting research as temple repairs. Alternative development models can be created from the results of research on tourist preferences and development strategies for Mendut Temple and Pawon Temple each. Based on the results of the research and conclusions obtained, the suggestions that can be given are as follows;

Collaboration between relevant agencies to develop both tourism and development to attract tourists, in addition, the promotion of Mendut and Pawon Temple cultural attractions need to be increased so that many tourists be aware of the existence of Mendut and Pawon Temples and then pay a visit.

The Magelang District Government cooperates with the Borobudur Conservation Center to attract tourists by making a continuous tour package which includes Borobudur Temple, Mendut Temple and Pawon Temple. With the package program, the level of visit in Mendut and Pawon Temples is expected to increase.

Improving services at Mendut Temple and Pawon Temple tourism objects in the form of culinary places and souvenir shops that are neatly arranged, cooperating with surrounding communities who have lands to use as parking lots expansion, and adding toilets that are professionally managed to ensure cleanliness. In addition to improving existing facilities, development need to be carried out in the environment around Mendut and Pawon temples so that it can become a tourist village that supports cultural tourism objects in Mendut and Pawon Temples.

\section{REFERENCES}

Alam, W.I., 2010. Indentifikasi Persepsi dan Preferensi Pengunjung Tentang Objek dan Daya Tarik Wisata Situ Bagendit Kabupaten Garut. Skripsi. Bandung: Program Studi Perencanaan Wilayah dan Kota Fakultas Teknik dan Ilmu Komputer Universitas Komputer Indonesia.

Arsyad, Lincoln., 2010. Ekonomi Pembangunan. 5th ed. UPP STIM YKPN. Yogyakarta.

Fitrianti, H., 2014. Strategi Pengembangan Desa Wisata Talun Melalui Model Pemberdayaan Masyarakat. Economic Development Analysis Journal, 3(1), pp.204-211.

Gantini, K.D.\&.S.H.P.D., 2012. Pengaruh Revitalisasi Produk Terhadap Preferensi Mengunjungi Lembah Bougenville Resort. Tourism and Hospitally Essentials (THE), 2(2), pp.387-406.

Hanif, L., Fafurida., 2018. Development Strategy of Small Industry of Typical Food as Supporting Tourism Sector. Jurnal Ekonomi dan Kebijakan, (1), pp.6277.

Khaironi., Soesilowati, E., Arsal, T., 2017. Kearifan Lokal Masyarakat Etnis Gayo sebagai Destinasi Wisata Budaya di Kota Takengon. Journal of Educational Social Studies, 6(3), pp 99-110.

Pradikta, A., 2013. Strategi Pengembangan Obyek Wisata Waduk Gunungrowo Indah Dalam Upaya Meningkatkan Pendapatan Asli Daerah (PAD) Kabupaten Pati. Economics Development Analysis Journal , 2(4), pp.246-256.

Pujiati, A., 2009. Analisis Kawasan Andalan Di Jawa Tengah. Jurnal Ilmu Ekonomi Aset, pp 117-128.

Rahman, Y. A., \& Chamelia, A. L. (2015). Faktor-Faktor yang Mempengaruhi PDRB Kabupaten / Kota Jawa Tengah Tahun 2008-2012. Jurnal Ekonomi dan Kebijakan, 8(1). Pp 88-99

Spillane, James J., 1991. Ekonomi Pariwisata Sejarah dan Prospeknya. Yogyakarta: Kanisius

Yoeti, O.A., 2008. Ekonomi Pariwisata Indonesia : Introduksi, Informasi, dan Implementasi. Jakarta : Kompas 


\section{APPENDIX}

Table 5. Average Results of Weighting and Internal Strategy Rating Factors Mendut Temple Attractions

\begin{tabular}{|c|c|c|c|}
\hline Internal Strategic Factors & B & $\mathbf{R}$ & Score \\
\hline Strenght & 0,14 & 4 & 0,56 \\
\hline The strategic location of Mendut Temple and Pawon Temple & & & \\
\hline $\begin{array}{l}\text { Comfortable atmosphere at Mendut Temple and Pawon Temple } \\
\text { attractions }\end{array}$ & 0,12 & 4 & 0,48 \\
\hline The existence of supporting transportation facilities & 0,11 & 3,5 & 0,39 \\
\hline Affordable ticket prices & 0,14 & 4 & 0,56 \\
\hline $\begin{array}{l}\text { Friendliness of the people around Mendut Temple and Pawon Temple to } \\
\text { tourists }\end{array}$ & 0,08 & 3,5 & 0,28 \\
\hline $\begin{array}{l}\text { Professional management of Mendut Temple and Pawon Temple } \\
\text { attractions }\end{array}$ & 0,09 & 3,5 & 0,31 \\
\hline Cleanliness of Mendut Temple and Pawon Temple attractions & 0,09 & 4 & 0,36 \\
\hline NUMBER OF STRENGTH SCORES & & & 2,94 \\
\hline Weakness & 0,10 & 1,5 & 0,15 \\
\hline \multicolumn{4}{|l|}{ Lack of attractions owned by Mendut Temple } \\
\hline The lack of facilities owned by Mendut Temple & 0,09 & 1 & 0,09 \\
\hline The development of Mendut Temple and Pawon Temple is still simple & 0,12 & 1 & 0,12 \\
\hline Lack of promotion from Mendut Temple attractions & 0,11 & 1,5 & 0,16 \\
\hline $\begin{array}{l}\text { The land owned by Mendut Temple is very limited so it is difficult to } \\
\text { develop }\end{array}$ & 0,11 & 1 & 0,11 \\
\hline NUMBER OF WEAKNESS SCORES & & & 0,635 \\
\hline
\end{tabular}

Source: Primary data processed 2018 
Table 6. Average Weighting Results

and External Strategy Factor Ratings Mendut Temple Attractions

\begin{tabular}{|c|c|c|c|}
\hline External Strategic Factors & B & $\mathrm{R}$ & Score \\
\hline Opportunity & 0,11 & 3,5 & 0,385 \\
\hline \multicolumn{4}{|l|}{ The accessibility level of Mendut Temple and Pawon Temple is easy } \\
\hline \multirow[t]{2}{*}{ The collaboration between Mendut Temple managers and related agencies } & 0,0 & 3 & 0,27 \\
\hline & 9 & & \\
\hline Regional autonomy gives flexibility to develop existing tourism promotions & $\mathrm{o}, \mathrm{o}$ & 3 & 0,27 \\
\hline $\begin{array}{l}\text { The surrounding environment of Mendut Temple in the form of countryside and } \\
\text { culture can be developed and used as a tourist attraction from Mendut Temple }\end{array}$ & $\begin{array}{l}9 \\
0,11\end{array}$ & 3,5 & 0,385 \\
\hline $\begin{array}{l}\text { The potential that Mendut Temple has which leads to current character and } \\
\text { cultural education }\end{array}$ & 0,11 & 4 & 0,44 \\
\hline NUMBER OF OPPORTUNITIES SCORES & & & 1,75 \\
\hline Threat & 0,0 & 3 & 0,24 \\
\hline $\begin{array}{l}\text { The existence of other tourist objects that began to emerge and develop added } \\
\text { competitiveness }\end{array}$ & 8 & & \\
\hline \multirow[t]{2}{*}{ There are potential similarities with tourism objects in other regions } & 0,0 & 1,5 & 0,105 \\
\hline & 7 & & \\
\hline \multirow[t]{2}{*}{ The environmental damage around Mendut Temple and Pawon Temple } & 0,0 & 2 & 0,18 \\
\hline & 9 & & \\
\hline Interest of tourists who start a little to visit cultural attractions such as Mendut & 0,0 & 2 & 0,18 \\
\hline Temple & 9 & & \\
\hline \multirow[t]{2}{*}{ The awareness of tourists to keep Mendut temple attractions is still low } & 0,0 & 3 & 0,27 \\
\hline & 9 & & \\
\hline $\begin{array}{l}\text { The distance between the highway and the large cargo with Mendut Temple is too } \\
\text { close }\end{array}$ & 0,0 & 4 & 0,36 \\
\hline NUMBER OF THREATS SCORES & 9 & & 1,335 \\
\hline
\end{tabular}

Source: Primary data processed 2018 
Table 7. Average Weighting Results and Internal Strategy Rating Factors Temple Pawon Tourism Objects

Internal Strategic Factors B $\quad$ R Score

Strenght

$0,13 \quad 4 \quad 0,52$

The strategic location of Mendut Temple and Pawon Temple

Comfortable atmosphere at Mendut Temple and Pawon Temple attractions

$0,10 \quad 3, \quad 0,35$

The existence of supporting transportation facilities 5

Affordable ticket prices

$0,10 \quad 3, \quad 0,35$

5

Friendliness of the people around Mendut Temple and Pawon Temple to $0,14 \quad 4 \quad 0,56$ tourists

$0,09 \quad 3, \quad 0,315$

Professional management of Mendut Temple and Pawon Temple 5 attractions

$0,09 \quad 3, \quad 0,315$

Cleanliness of Mendut Temple and Pawon Temple attractions

NUMBER OF STRENGTH SCORES

$$
0,09 \quad 4 \quad 0,36
$$

Weakness

Lack of attractions owned by Pawon Temple

The lack of facilities owned by Mendut Temple

The development of Mendut Temple and Pawon Temple is still simple

$\begin{array}{lll} & & 2,77 \\ 0,08 & 1, & 0,12 \\ & 5 & \\ 0,08 & 1 & 0,08 \\ 0,10 & 1 & 0,10\end{array}$

Lack of promotion from Pawon Temple attractions

$0,09 \quad 1, \quad 0,135$

5

The land owned by PawonTemple is very limited so it is difficult to develop $\quad \begin{array}{llll}0,09 & 1 & 0,09\end{array}$ NUMBER OF WEAKNESS SCORES 
Table 8. Average Weighting Results

and External Strategy Factor Rating Candi Pawon Tourism Object

External Strategic Factors

B R Score

Opportunity

$0,11 \quad 3,5 \quad 0,385$

The accessibility level of Mendut Temple and Pawon Temple is easy

The collaboration between Pawon Temple managers and related $0,10 \quad 3 \quad 0,3$ agencies

Regional autonomy gives flexibility to develop existing tourism $0,09 \quad 3 \quad 0,27$ promotions

The surrounding environment of PawonTemple in the form of $0,12 \quad 4 \quad 0,48$ countryside and culture can be developed and used as a tourist attraction from Mendut Temple

The potential that Pawon Temple has which leads to current character $\quad 0,11 \quad 4 \quad 0,44$ and cultural education

NUMBER OF OPPORTUNITIES SCORES

Threat

1,875

The existence of other tourist objects that began to emerge and develop added competitiveness

There are potential similarities with tourism objects in other regions

The environmental damage around Mendut Temple and Pawon Temple

Interest of tourists who start a little to visit cultural attractions such as PawonTemple

The awareness of tourists to keep Pawon temple attractions is still low

The distance between the highway and the large cargo with Pawon

Temple is too close

$0,09 \quad 3 \quad 0,27$

NUMBER OF THREATS SCORES

$0,08 \quad 1,5 \quad 0,12$

$0,08 \quad 2 \quad 0,16$

$\begin{array}{lll}0,09 & 2 & 0,18\end{array}$

$\begin{array}{lll}0,09 & 2 & 0,18\end{array}$

$0,09 \quad 4 \quad 0,36$

Source: Primary data processed 2018 